\title{
Faktor-Faktor Yang Mempengaruhi Mahasiswa Angkatan 2016 dan Angkatan 2017 dalam Memilih Program Studi (Studi Kasus: Program Studi Teknik Industri Universitas XYZ)
}

\section{Factors Affecting Class 2016 and Class 2017 Students Choosing Study Program (Case Study: Industrial Engineering Study Program, XYZ University)}

\author{
Melina Hermawan \\ Fakultas Teknik, Program Studi Teknik Industri, Universitas Kristen Maranatha \\ Email: melina.hermawan@eng.maranatha.edu
}

\begin{abstract}
Abstrak
Universitas beroperasi dalam situasi kompetitif, oleh karena itu, penting untuk memahami tentang bagaimana cara menarik mahasiswa dan bagaimana caranya memasarkan universitas itu sendiri. Penelitian untuk mengetahui faktor-faktor yang mempengaruhi angkatan 2016 dan angkatan 2017 dalam pemilihan program studi Teknik Industri dengan variabel bebas faktorfaktor pemilihan universitas dan program studi. Kuesioner dikembangkan dengan menggunakan 7 skala Likert dengan 58 faktor. Analisis faktor dan analisis reliabilitas digunakan untuk menguji validitas dan reliabilitas kuesioner. Analisis Regresi Berganda digunakan untuk mengetahui faktor-faktor mana yang berpengaruh signifikan. Hasil penelitian menunjukkan bahwa model memiliki R2 sebesar 75,3\% variabel independen menjelaskan hubungan secara linier terhadap variabel dependen, dengan 8 faktor yang dianggap signifikan yaitu Banyaknya publikasi buku yang ditulis oleh dosen, Kemudahan mendapatkan tempat kost, Peringkat universitas dibandingkan universitas negeri dan swasta lainnya, Menariknya talk show promosi Teknik Industri di radio, Universitas memiliki banyak unit kegiatan mahasiswa, Menariknya mata kuliah yang diajarkan di program studi Teknik Industri, Luas ruang kuliah.
\end{abstract}

Kata kunci: Regresi Berganda, Pemilihan Universitas, Pemilihan Program Studi

\begin{abstract}
Universities are operating in competitive situations therefore, it is important for the university to understand how to attract students and how to market themself. This research was conducted to find factors affecting student class 2016 and class 2017 in choosing University and study program in Industrial Engineering for a first-year student in a University, Bandung, Indonesia. Questionnaires were developed using 7 Likert's scale with 58 factors considered. Factor analysis and Reliability analysis were used to test the validity and reliability of the questionnaires. Multiple Regression Analysis was used to find which factors have significant influences. The result showed that the model has $R 2$ of 75,3\% independent variables explain the linear relationship to the dependent variable with 8 factors considered as significant factors i.e. The number of book publications written by the lecturer, Easier of getting dormitory, University rankings compared to other public and private universities, Interestingly industrial engineering promotion talk shows on radio, the University has many student activity units. Interestingly of subject Industrial Engineering study program, the large of classroom.
\end{abstract}

Keywords: Multiple Regression, Indonesia Student, University Selection, Study Program Selection

\section{Pendahuluan}

Banyak program promosi yang dilakukan oleh universitas yang selama ini dilakukan secara terpusat, namun jumlah mahasiswa cenderung mengalami penurunan (Yulianti \& Sutjiati, 2008). Kebutuhan pemasaran dan elemen-elemennya sebagian besar dirasakan oleh PTS swasta, yang muncul dan telah tumbuh secara signifikan tidak hanya dalam kapasitas dan program studinya, tetapi juga memperbaiki citra mereka (Manoku, 2014). Saat ini, pengambilan keputusan menjadi lebih kompleks dan dianggap sangat penting bagi konsumen. Universitas menghadapi perubahan cepat lingkungan 
bisnis global yang kompetitif (Muniady, 2014). Perguruan Tinggi harus membuat dan memasarkan program studi dengan mempertimbangkan dua utama pemangku kepentingan (Kusumawati, 2013)

Penelitian ini diharapkan dapat memberikan gambaran untuk Program Studi Teknik Industri tentang bagaimana perilaku calon mahasiswa kemudian dapat menentukan strategi program pemasaran kepada siswa SMA sebagai calon mahasiswa baru. Untuk berpartisipasi dalam pasar pendidikan tinggi, universitas dan fakultas harus membuat bauran pemasaran sendiri yang sesuai calon pelanggan (Muskinja, 2013). Feedback Penelitian serupa tentang program pemasaran pernah dilakukan dengan usulan untuk keseluruhan program studi dan fakultas yaitu tentang "Usulan Bauran Pemasaran dalam Upaya Meningkatkan Jumlah Mahasiswa Baru Universitas XYZ" (studi kasus Siswa SMA di Kota Bandung) yang dilakukan oleh Yulianti \& Gozaly (2008) dan "Usulan Bauran Pemasaran dalam Upaya Meningkatkan Jumlah Mahasiswa Baru Universitas XYZ" (studi kasus Siswa SMA di Wilayah Jawa kecuali Kota Bandung) yang dilakukan oleh Yulianti \& Sutjiati (2008).

\section{Tinjauan Pustaka}

\subsection{Perilaku Pembelian Konsumen}

Perilaku pembelian konsumen dipengaruhi oleh faktor-faktor budaya, sosial, pribadi, dan psikologis. Faktor-faktor budaya mempunyai pengaruh paling luas dan paling dalam (Kotler, 2016). Berikut ini adalah faktor-faktor yang mempengaruhi perilaku pembelian konsumen :

Faktor Psikologis (Kotler, 2016)

- Motivasi

Seseorang memiliki banyak kebutuhan pada waktu tertentu, beberapa kebutuhan bersifat biogenis, kebutuhan tersebut muncul dari tekanan biologis seperti lapar, haus, tidak nyaman. Kebutuhan lain bersifat psikogenis; kebutuhan itu muncul dari tekanan psikologis seperti kebutuhan akan pengakuan, penghargaan, atau rasa keanggotaan kelompok. Suatu kebutuhan akan menjadi motif yaitu kebutuhan yang cukup mendorong seseorang untuk bertindak, hingga mencapai tingkat intensitas yang memadai.

- Persepsi

Seseorang yang termotivasi siap untuk bertindak. Bagaimana seseorang yang termotivasi bertindak akan dipengaruhi oleh persepsinya terhadap situasi tertentu, persepsi adalah proses yang digunakan oleh seorang individu untuk memilih, mengorganisasi, dan menginterpretasi masukan-masukan informasi guna menciptakan gambaran dunia yang memiliki arti.

- Pembelajaran

Sebagian besar perilaku manusia adalah hasil dari belajar. Ahli teori pembelajaran yakin bahwa pembelajaran dihasilkan melalui perpaduan kerja antara dorongan, rangsangan, petunjuk bertindak, tanggapan, dan penguatan.

- Keyakinan dan Sikap

Keyakinan adalah gambaran pemikiran yang dianut seseorang tentang suatu hal sedangkan sikap adalah evaluasi, perasaan emosional, dan kecenderungan tindakan yang menguntungkan atau tidak menguntungkan dan bertahan lama dari seseorang terhadap suatu obyek gagasan.

\subsection{Tahap-tahap Proses Keputusan Pembelian (Kotler, 2016)}

Selain berbagai pengaruh yang mempengaruhi pembelian, Berikut cara konsumen mengambil keputusan pembelian yang terdiri dari lima tahap sebagai berikut:

- Tahap 1: Pengenalan Masalah

Proses pembelian dimulai saat pembeli mengenali sebuah masalah atau kebutuhan tersebut dapat dicetuskan oleh rangsangan internal atau eksternal. Pemasar perlu mengidentifikasi keadaan yang memicu kebutuhan tertentu dengan mengumpulkan informasi dari sejumlah konsumen, pemasar dapat mengidentifikasi rangsangan yang paling sering membangkitkan minat akan suatu kategori produk. Pemasar kemudian dapat mengembangkan strategi pemasaran yang memicu minat konsumen. 
- Tahap 2: Pencarian Informasi

Konsumen yang tergugah kebutuhannya akan terdorong untuk mencari informasi yang lebih banyak. Situasi pencarian informasi lebih ringan dinamakan perhatian yang menguat. Pada tingkat itu seseorang hanya menjadi lebih peka terhadap informasi tentang produk.

- Tahap 3: Evaluasi Alternatif

Konsumen sebagai proses yang berorientasi kognitif, yaitu konsumen membentuk penilaian atas produk terutama secara sadar dan rasional. Beberapa konsep dasar tentang proses evaluasi konsumen. Pertama, konsumen berusaha untuk memenuhi suatu kebutuhan. Kedua, konsumen mencari manfaat tertentu dari solusi produk. Ketiga, konsumen memandang masing-masing produk sebagai sekumpulan atribut dengan kemampuan yang berbeda-beda dalam memberikan manfaat yang digunakan untuk memuaskan kebutuhan itu.

- Tahap 4: Keputusan Pembelian

Dalam tahap evaluasi, konsumen membentuk preferensi atas merek-merek dalam kumpulan pilihan dan juga mungkin membentuk niat untuk membeli produk yang paling disukai.

- Tahap 5: Perilaku Pascapembelian

Setelah membeli produk, konsumen akan mengalami level kepuasan atau ketidakpuasan tertentu.

Tugas pemasaran tidak berakhir saat produk dibeli, melainkan berlanjut hingga periode pasca pembelian.

\subsection{Metode Multiple Regression Analysis (Hair, 2014)}

Metode ini digunakan untuk mengetahui variabel yang dapat mempengaruhi, seberapa besar pengaruhnya beserta model regresinya. Metode yang digunakan adalah Stepwise karena metode tersebut akan memberikan model terbaik dari sebuah analisis regresi. Variabel yang masuk pada model regresi dengan metode Stepwise adalah variabel yang mempunyai korelasi tertinggi dan berpengaruh terhadap variabel dependen. Model regresi yang dihasilkan oleh Multiple Regression Analysis yaitu:

$$
\begin{array}{ll}
\mathrm{Y}=\mathrm{a} & +\mathrm{b}_{1} \mathrm{X}_{1}+\mathrm{b}_{2} \mathrm{X}_{2}+\mathrm{b}_{\mathrm{i}} \mathrm{X}_{\mathrm{i}} \\
\mathrm{Y} & =\text { Variabel terikat } \\
\mathrm{X} & =\text { Variabel bebas } \\
\mathrm{a} & =\text { Konstanta } \\
\mathrm{b} & =\text { Koefisien variabel bebas }
\end{array}
$$

$R$ Square menunjukkan besar persentase variabilitas variabel dependen yang dijelaskan oleh variabel independen. Nilai $R$ Square adalah nol sampai dengan 1. Jika nilai $R$ Square mendekati 1 berarti hampir semua variabel indenpenden mampu menjelaskan variabel dependen.

\section{Pembahasan}

\subsection{Rancangan Penelitian}

Penelitian dilakukan untuk melihat faktor-faktor yang mempengaruhi mahasiswa dalam pemilihan universitas dan program studi. Variabel independen (variabel bebas) adalah tingkat kinerja faktorfaktor pemilihan universitas (Tabel 2) dan program studi (Tabel 3) yang berasal dari hasil pengembangan penelitian Alonderiene (Alonderiene; 2013). Variabel dependen (variabel terikat) yang digunakan berupa keputusan mahasiswa dalam memilih program studi yaitu pernyataan keyakinan memilih program studi Teknik Industri Universitas XYZ.

Pengumpulan data dilakukan dengan menyebarkan kuesioner kepada seluruh anggota populasi mahasiswa Teknik Industri angkatan 2016 sebanyak 70 orang pada saat semester genap 2017/2018 dan angkatan 2017 sebanyak 58 orang pada saat semester ganjil 2018/2019.

Kuesioner disusun dalam 2 bagian yaitu bagian 1 berisi informasi profil responden yang bertujuan mengetahui informasi asal SMA (Sekolah Menengah Atas), pendidikan dan pekerjaan, serta penghasilan orang tua, sumber informasi tentang Teknik Industri Universitas XYZ, Universitas dan program studi yang didaftar selain Universitas XYZ dan bulan pendaftaran ke Teknik Industri Universitas XYZ. Skala digunakan skala nominal. Kuesioner bagian 2 untuk mengetahui faktorfaktor yang dianggap penting oleh mahasiswa ketika akan memilih universitas dan mengetahui 
penilaian mahasiswa terhadap kinerja program studi Universitas XYZ. Skala untuk penilaian kinerja digunakan skala likert dengan penilaian 1-7 (sangat tidak baik, tidak baik, cukup tidak baik, cukup, cukup baik, baik, sampai sangat baik). Skala untuk tingkat kepentingan digunakan skala likert dengan penilaian 1-7 (sangat tidak penting, tidak penting, cukup tidak penting, cukup, cukup penting, penting, sampai sangat penting).

Tabel 1. Faktor-Faktor Pemilihan Universitas

\begin{tabular}{|c|c|}
\hline Competence of Lecturers & Universitas memiliki dosen-dosen yang sudah terkenal \\
\hline $\begin{array}{l}\text { Learning methods, } \\
\text { research conducted }\end{array}$ & $\begin{array}{l}\text { universitas banyak mempublikasikan penemuan-penemuan yang bisa } \\
\text { diterapkan di masyarakat }\end{array}$ \\
\hline $\begin{array}{l}\text { International exchange } \\
\text { options }\end{array}$ & universitas bekerja sama dengan universitas lain di luar negeri \\
\hline \multirow[t]{5}{*}{ Universtiy reputation } & universitas dikenal banyak orang \\
\hline & universitas telah lama berdiri \\
\hline & universitas memiliki reputasi yang baik \\
\hline & akreditas universitas \\
\hline & peringkat universitas dibandingkan dengan universitas negeri dan swasta lainnya \\
\hline \multirow[t]{2}{*}{ Carrer (job) possibilities } & universitas banyak bekerjasama dengan perusahaaan \\
\hline & lulusan universitas banyak dicari oleh perusahaan \\
\hline \multirow{4}{*}{$\begin{array}{l}\text { Opinion/advice of other } \\
\text { people }\end{array}$} & universitas yang dipandang baik oleh diri sendiri \\
\hline & universitas yang dipandang baik oleh orang tua \\
\hline & universitas yang dipandang baik oleh teman \\
\hline & universitas yang dipandang baik oleh guru di sekolah \\
\hline \multirow[t]{4}{*}{ Social life } & lokasi universitas di kota yang sejuk \\
\hline & jarak universitas terhadap tempat tinggal \\
\hline & $\begin{array}{l}\text { suasana kristiani yang terlihat dari banyaknya aktivitas persekutuan mahasiswa } \\
\text { kristen di universitas }\end{array}$ \\
\hline & suasana kristiani yang terlihat dari sikap mahasiswa di universitas \\
\hline \multirow[t]{8}{*}{ Infrastructure } & kelengkapan buku-buku di perpustakaan \\
\hline & luas ruang kuliah \\
\hline & kelengkapan fasilitas ruang kuliah \\
\hline & kelengkapan laboratorium komputer \\
\hline & luas food court yang dimiliki universitas \\
\hline & kelengkapan makanan di food court universitas \\
\hline & universitas memiliki banyak unit kegiatan maasiswa sesuai minat mahasiswa \\
\hline & banyaknya jumlah gelombang penerimaan mahasiswa baru \\
\hline Infrastructure & kemudahan mendapatkan informasi tentang persyaratan jalur pmdk \\
\hline \multirow[t]{4}{*}{ Costs } & besarnya kemungkinan ditrima di jalur pmdk \\
\hline & banyaknya program beasiswa yang ditawarkan \\
\hline & kemudahan mendapatkan tempat kos \\
\hline & biaya hidup yang murah di kota tempat universitas berada \\
\hline \multirow[t]{3}{*}{ Information Sources } & universitas sering melakukan promosi di sekolah-sekolah menengah atas \\
\hline & universtias sering mengiklankan pembukaan ujian saringan masuk di koran \\
\hline & universitas memiliki situs/website yang informatif \\
\hline
\end{tabular}


Tabel 2. Faktor-Faktor Pemilihan Program Studi

\begin{tabular}{|c|c|}
\hline \multirow[t]{3}{*}{$\begin{array}{l}\text { Students inidividual } \\
\text { characteristics }\end{array}$} & $\begin{array}{l}\text { jumlah mahasiswa laki-laki dibandingkan dengan jumlah mahasiswa perempuan } \\
\text { di Teknik Industri }\end{array}$ \\
\hline & $\begin{array}{l}\text { jumlah mahasiswa yang beretnis tionghoa dibandingkan dengan mahasiswa } \\
\text { yang beretnis lainnya di Teknik Industri }\end{array}$ \\
\hline & $\begin{array}{l}\text { Jumlah mahasiswa yang memiliki gaya hidup sederhana (tidak boros dalam } \\
\text { pengeluaran sehari-hari) di Teknik Industri }\end{array}$ \\
\hline \multirow[t]{2}{*}{ Possibility to be admitted } & kemudahan diterima di program studi teknik industri \\
\hline & kemudahan ujian saringan masuk ke program studi teknik industri \\
\hline \multirow[t]{2}{*}{ Possibility to be admitted } & ringannya masa orientasi mahasiswa \\
\hline & murahnya biaya kuliah di program studi teknik industri \\
\hline \multirow{11}{*}{$\begin{array}{l}\text { Study program-related } \\
\text { factors }\end{array}$} & akreditasi program studi teknik industri \\
\hline & program studi yang disarankan berdasarkan hasil psikotes \\
\hline & menariknya mata kuliah yang diajarkan di program studi teknik industri \\
\hline & rasa bangga jika memiliki gelar ST teknik industri \\
\hline & kemudahan diterima kerja bila lulusan teknik industri \\
\hline & Fleksibilitas karir (kerja) lulusan Teknik Industri \\
\hline & Banyaknya mahasiswa Teknik yang memenangkan berbagai perlombaan \\
\hline & menariknya open house hasil karya mahasiswa-mahasiswa teknik industri \\
\hline & menariknya topik-topik penelitian mahasiswa program studi teknik industri \\
\hline & banyaknya acara yang diponsori oleh program studi teknik industri \\
\hline & menariknya penjelasan promosi teknik industri di sekolah-sekolah \\
\hline \multirow{3}{*}{$\begin{array}{l}\text { Study program-related } \\
\text { factors }\end{array}$} & menariknya talk show promosi teknik industri di radio \\
\hline & banyaknya pelatihan-pelatihan yang dilakukan program studi teknik industri \\
\hline & banyaknya publikasi ilmiah dari dosen-dosen program studi teknik industri \\
\hline \multirow[t]{4}{*}{$\begin{array}{l}\text { Study program-related } \\
\text { factors }\end{array}$} & $\begin{array}{l}\text { banyaknya publikasi buku yang ditulis oleh dosen-dosen program studi teknik } \\
\text { industri }\end{array}$ \\
\hline & kelengkapan fasilitas laboratorium program studi teknik industri \\
\hline & $\begin{array}{l}\text { banyaknya jumlah mahsiswa yang beragama Kristen di program studi teknik } \\
\text { industri }\end{array}$ \\
\hline & $\begin{array}{l}\text { banyaknya jumlah dosen yang beragama Kristen di program studi teknik } \\
\text { industri }\end{array}$ \\
\hline
\end{tabular}

Sumber: Alonderiene, 2013 


\section{UNIVERSITY AND STUDY PROGRAM SELECTION FACTORS}

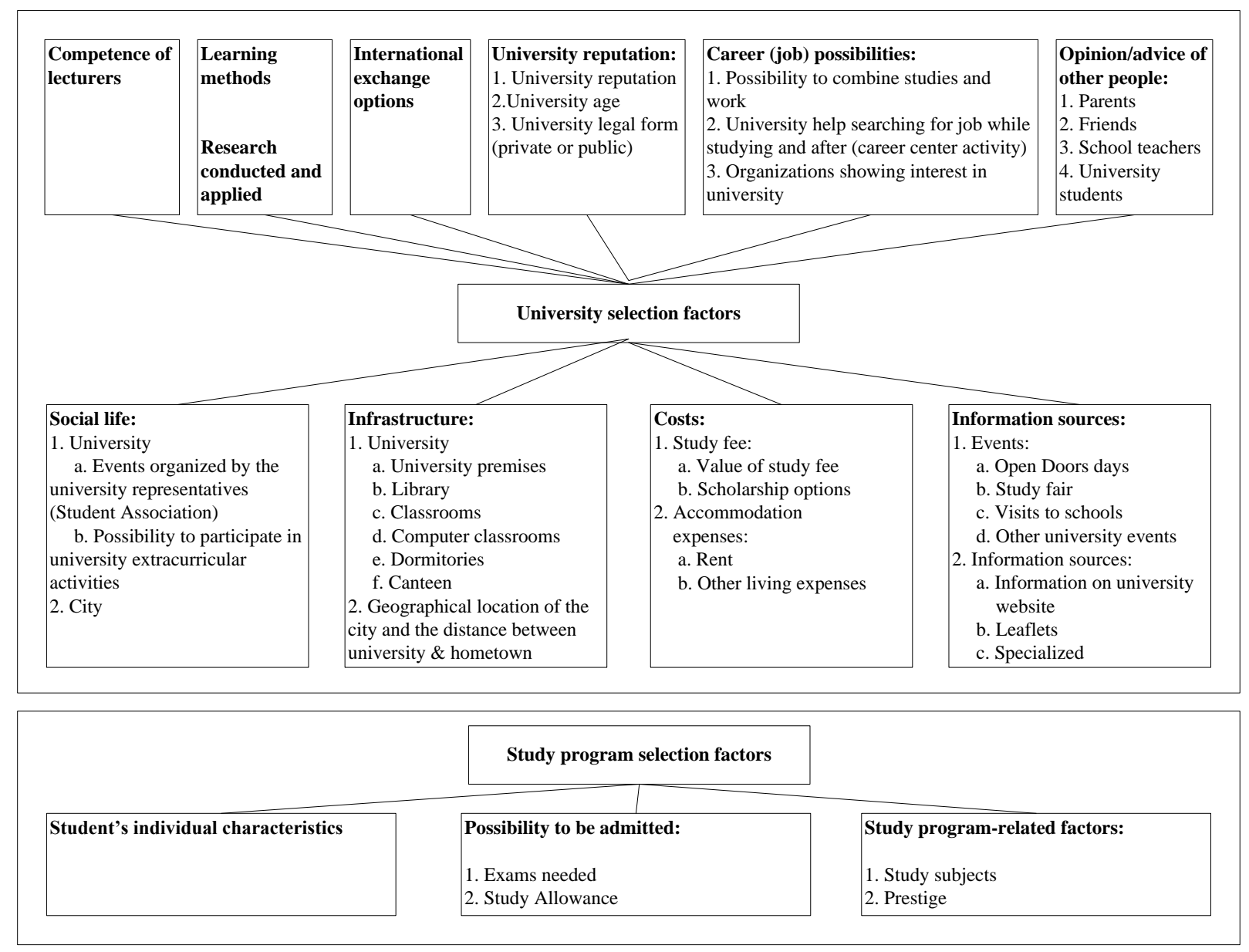

Gambar 1. Faktor Pemilihan Universitas dan Program Studi (Alonderiene, 2013).

\subsection{Hasil Kuesioner Penelitian Angkatan 2016}

\subsubsection{Pengujian Validitas Tingkat Kinerja dan Tingkat Kepentingan}

Setelah pengumpulan kuesioner, dilakukan uji validitas untuk mengetahui ketepatan fungsi alat ukur. Jika nilai Corrected Item-Total Correlation lebih kecil $r$ tabel maka variabel tersebut tidak valid, variabel tersebut dihilangkan dalam penelitian, jika masih ada pertanyaan lain yang dapat mewakili variabel (Sekaran, 2016). Data tingkat kinerja dan tingkat kepentingan untuk tiap faktor pemilihan universitas dan program studi dilakukan uji validitas dengan menggunakan bantuan SPSS (Reliability Analysis) dan membandingkan hasil output dari SPSS dengan nilai $\mathrm{r}$ kritik dari tabel $R$ Pearson dengan taraf kepercayaan 5\% untuk $\mathrm{N}=70$ adalah 0.232 . Pengujian validitas dengan membandingkan Corrected Item-Total Correlation hasil keluaran SPSS dengan nilai r kritik 0,232 menunjukkan hasil bahwa data tingkat kinerja variabel dinyatakan valid dan untuk tingkat kepentingan variabel dinyatakan juga valid kecuali variabel $26,47,48$, dan 60 dinyatakan tidak valid.

\subsubsection{Pengujian Reliabilitas Tingkat Kinerja dan Tingkat Kepentingan}

Setelah dinyatakan valid, data tingkat kinerja dan tingkat kepentingan untuk tiap faktor pemilihan universitas dan program studi diuji reliabilitas dengan melihat nilai Cronbach's Alpha. Uji Reliabilitas dilakukan untuk mengetahui keandalan suatu alat ukur yang digunakan (Sekaran, 2016). Data yang diuji adalah variabel tingkat kepentingan, tingkat kinerja dan tingkat keyakinan. Jika Cronbach's Alpha lebih besar 0.7 kesimpulannya adalah variabel reliabel. Dari pengolahan diperoleh nilai reliabilitas sebesar 0,980, untuk variabel tingkat kinerja dan nilai reliabilitas sebesar 0,956 untuk 
variabel tingkat kepentingan dengan jumlah sampel sebanyak 70 untuk 63 buah pernyataan. Nilai reliabilitas ini berada di antara 0,9 dan 1 , yang artinya kuesioner yang digunakan dalam penelitian ini memiliki nilai reliabilitas yang tinggi.

\subsubsection{Pengolahan Data Menggunakan Regresi Linier Berganda}

Data tingkat kinerja dimasukan ke program SPSS sebagai variabel bebas dan data keyakinan memilih program studi Teknik Industri Universitas XYZ sebagai variabel terikat. Analisis regresi linier menggunakan menu Analyse Regression Linier dilakukan dengan menggunakan metode stepwise.

Nilai koefisien determinasi dari model regresi linier adalah 0.281, yang berarti model regresi mampu menjelaskan fenomena faktor pemilihan universitas dan program studi berkorelasi dengan pernyataan keyakinan memilih program studi Teknik Industri Universitas XYZ hanya sebesar $28.1 \%$.

Untuk melihat adanya pengaruh kinerja terhadap keyakinan pemilihan universitas dan program, dilakukan perhitungan ANOVA yang menunjukkan nilai sig yang di bawah 0,05 artinya ada pengaruh dari kinerja faktor-faktor pemilihan universitas dan program studi terhadap keyakinan pemilihan Program Studi Teknik Industri Universitas XYZ.

Untuk melihat berapa besar pengaruh dari masing-masing variabel dilakukan perhitungan Koefisien Regresi untuk masing-masing variabel dengan persamaan regresi yang terbentuk adalah:

$\mathrm{Y}=3.743+0.280 \mathrm{X} 59-0.275 \mathrm{X} 32+0.272 \mathrm{X} 11-0.185 \mathrm{X} 54$

Dimana:

$\mathrm{Y} \quad=$ Keyakinan dalam memilih program studi Teknik Industri Universitas XYZ

X59 = Banyaknya publikasi buku yang ditulis oleh dosen program studi Indonesia.

$\mathrm{X} 32$ = Kemudahan mendapatkan tempat kost

$\mathrm{X} 11$ = Peringkat universitas dibandingkan universitas negeri dan swasta lainnya.

X54 = Menariknya talk show promosi Teknik Industri di radio

\subsubsection{Statistik Deskriptif dari Variabel yang Berpengaruh}

Berdasarkan statistik deskriptif rata -rata tingkat kepentingan dan rata-rata tingkat kinerja serta koefisien model regresi maka faktor universitas dan faktor program studi yang mempengaruhi keyakinan pemilihan program Studi Teknik Industri Universitas XYZ sebagai berikut:

$\mathrm{X} 11$ : Peringkat Universitas dibandingkan dengan universitas negeri dan swasta lainnya memiliki tingkat kinerja 5,0000 menunjukkan bahwa peringkat Universitas XYZ dinilai Cukup Baik, sedangkan tingkat kepentingan adalah 6,1571 artinya Penting. Koefisien regresi sebesar $+0,272$ menunjukkan semakin tinggi peringkat maka semakin tinggi keyakinan mahasiswa memilih program studi Teknik Industri Universitas XYZ. Hal ini didukung dengan urutan rangking prioritas yaitu faktor kualitas pendidikan menjadi prioritas pertama dalam memilih sebuah universitas bagi mahasiswa angkatan 2016. Sedangkan faktor dengan prioritas terakhir dalam memilih unversitas adalah usia dosen pengajar. Pandangan positif mahasiswa menyatakan kualitas pendidikan terjamin sebesar 45,7\%. Oleh karena itu Universitas XYZ perlu pengelolaan dengan lebih baik agar peringkat yang telah diraih dapat dipertahankan dan bahkan ditingkatkan.

X32 : Kemudahan mendapatkan tempat kost, memiliki tingkat kinerja 5,5429 cenderung baik dengan tingkat kepentingan 5,8286 cenderung penting. Koefisien regresi -0.275 menunjukkan kemudahan dapat tempat kost rendah semakin tinggi keyakinan pemilihan program studi. Hal ini dapat disebabkan sebagian besar mahasiswa berasal dari Bandung

X54 : Menariknya talk show Teknik Industri di radio, dengan tingkat kinerja 4,9143 mendekati cukup baik dan tingkat kepentingan 5,2143 cukup penting. Koefisien regresi $-0,185$ menunjukkan kemenarikan talk show rendah memperkuat keyakinan pemilihan Teknik Industri. Hal ini selaras dengan data bahwa iklan radio sebagai sumber info Teknik Industri mahasiswa hanya $2,1 \%$.

X59 : Banyaknya publikasi buku yang ditulis oleh Dosen Program Studi Teknik Industri, dengan tingkat kinerja sebesar 5,0571 baik dan tingkat kepentingan sebesar 5,4000 cenderung sangat penting. Koefisien regresi +0,280 menunjukkan semakin banyak 
publikasi buku maka tingkat keyakinan memilih program studi Teknik Industri Universitas XYZ semakin besar. Universitas XYZ perlu mendukung kegiatan publikasi dalam hal pendanaan dan diikuti oleh banyaknya dosen berpartisipasi menulis dan mempublikasikan buku.

\subsection{Hasil Kuesioner Penelitian Angkatan 2017}

\subsubsection{Pengujian Validitas Tingkat Kinerja dan Tingkat Kepentingan}

Data tingkat kinerja dan tingkat kepentingan untuk tiap faktor pemilihan universitas dan program studi dilakukan uji validitas dengan menggunakan bantuan SPSS (Reliability Analysis) dan membandingkan hasil output dari SPSS dengan nilai $r$ kritik dari tabel $\mathrm{R}$ Pearson dengan taraf kepercayaan $5 \%$ untuk $\mathrm{N}=58$ adalah 0.254 . Pengujian validitas dengan membandingkan corrected Item-Total Correlation hasil keluaran SPSS dengan nilai r kritik 0,254 menunjukkan hasil bahwa data tingkat kinerja variabel dan tingkat kepentingan variabel dinyatakan valid.

\subsubsection{Pengujian Reliabilitas Tingkat Kinerja dan Tingkat Kepentingan}

Setelah dinyatakan valid, data tingkat kinerja dan tingkat kepentingan untuk tiap faktor pemilihan universtias dan program studi diuji reliabilitas dengan melihat nilai Cronbach's Alpha diperoleh nilai reliabilitas sebesar 0,971, untuk variabel tingkat kinerja dan nilai reliabilitas sebesar 0,969 untuk variabel tingkat kepentingan dengan jumlah sampel sebanyak 58 untuk 63 buah pernyataan. Nilai reliabilitas ini berada di antara 0,9 dan 1 , yang artinya kuesioner yang digunakan dalam penelitian ini memiliki nilai reliabilitas yang tinggi.

\subsubsection{Pengolahan Data Menggunakan Regresi Linier Berganda}

Data tingkat kinerja dimasukan ke program SPSS sebagai variabel bebas dan data keyakinan memilih program studi Teknik Industri Universitas XYZ sebagai variabel terikat. Analisis regresi linier menggunakan menu Analyse Regression Linier dilakukan dengan menggunakan metode stepwise.

Nilai koefisien determinasi dari model regresi linier adalah 0.444, yang berarti model regresi mampu menjelaskan fenomena faktor pemilihan universitas dan program studi berkorelasi dengan pernyataan keyakinan memilih program studi Teknik Industri Universitas XYZ sebesar 44,4\%.

Untuk melihat adanya pengaruh kinerja terhadap keyakinan pemilihan universitas dan program, dilakukan perhitungan ANOVA yang menunjukkan nilai sig yang di bawah 0,05 artinya ada pengaruh dari kinerja faktor-faktor pemilihan universitas dan program studi terhadap keyakinan pemilihan Program Studi Teknik Industri Universitas XYZ.

Untuk melihat berapa besar pengaruh dari masing-masing variabel dilakukan perhitungan Koefisien Regresi untuk masing-masing variabel dengan persamaan regresi yang terbentuk adalah:

$\mathrm{Y}=2.851+0.326 \mathrm{X} 11-0.386 \mathrm{X} 26+0.190 \mathrm{X} 45+0.183 \mathrm{X} 21$

Dimana:

$\mathrm{Y} \quad=$ Keyakinan dalam memilih program studi Teknik Industri Universitas XYZ.

$\mathrm{X} 11$ = Peringkat universitas dibandingkan universitas negeri dan swasta lainnya.

$\mathrm{X} 26$ = Universitas memiliki banyak unit kegiatan mahasiswa yang sesuai minat mahasiswa.

X45 = Menariknya mata kuliah yang diajarkan di program studi Teknik Industri.

$\mathrm{X} 21$ = Luas ruang kuliah.

\subsubsection{Statistik Deskriptif dari Variabel yang Berpengaruh}

Berdasarkan statistik deskriptif rata-rata tingkat kepentingan dan rata-rata tingkat kinerja serta koefisien model regresi maka faktor universitas dan faktor program studi yang mempengaruhi keyakinan pemilihan program Studi Teknik Industri Universitas XYZ sebagai berikut:

$\mathrm{X} 11$ : Peringkat Universitas dibandingkan dengan universitas negeri dan swasta lainnya memiliki tingkat kinerja 5,6552 menunjukkan bahwa peringkat Universitas XYZ dinilai Baik, sedangkan tingkat kepentingan adalah 5,9828 artinya Penting. Koefisien regresi sebesar + 0,326 menunjukkan semakin tinggi peringkat maka semakin tinggi keyakinan mahasiswa memilih program studi Teknik Industri Universitas XYZ. Hal ini selaras 
dengan hasil rangking prioritas dimana faktor kualitas pendidikan menjadi prioritas pertama dalam memilih sebuah universitas bagi mahasiswa angkatan 2017. Sedangkan faktor dengan prioritas terakhir dalam memilih unversitas adalah usia dosen pengajar. Selain itu juga mahasiswa memiliki pandangan positif terhadap Teknik Industri Universitas XYZ dalam hal kualitas pendidikan terjamin sebesar 33,9\%. Namun pandangan negatif tentang akreditasi yang masih kurang sebesar 32\%. Oleh karena itu Universitas XYZ perlu pengelolaan dengan lebih baik agar peringkat yang telah diraih dapat dipertahankan dan bahkan ditingkatkan, yang memberikan suasana akademik bagi civitas akademika Teknik Industri dalam proses belajar mengajar sehingga akreditasi dapat ditingkatkan.

X21 : Luas ruang kuliah memiliki tingkat kinerja 5,8448 cenderung baik dengan tingkat kepentingan 5,7241 cenderung penting. Koefisien regresi +0,183 menunjukkan pemilihan program studi dipengaruhi oleh semakin luasnya ruang kuliah.

X26 : Universitas memiliki banyak unit kegiatan mahasiswa yang sesuai minat mahasiswa, dengan tingkat kinerja 5,9858 mendekati cukup baik dan tingkat kepentingan 6,0172 yaitu penting. Koefisien regresi -0,386 menunjukkan semakin sedikit unit kegiatan maka keyakinan pemilihan Teknik Industri Universitas XYZ semakin besar. Hasil ini tidak berbanding lurus dengan pernyataan tingkat kepentingan.

X45 : Menariknya mata kuliah yang diajarkan di program studi Teknik Industri, dengan tingkat kinerja sebesar 5,6897 cenderung baik dan tingkat kepentingan sebesar 5,9483 cenderung penting. Koefisien regresi $+0,190$ menunjukkan semakin menarik mata kuliah yang diajarkan di program Studi Teknik Industri maka tingkat keyakinan memilih program studi Teknik Industri Universitas XYZ semakin besar. Hasil ini selaras pandangan positif tentang Program Studi Teknik Industri Universitas XYZ dalam hal Lulusan dapat Bersaing sebesar 52,5\%, namun perlu diperhatikan mengenai pandangan negatif seputar perkuliahan dan tugas yang berat sebesar 39\%. Oleh karena itu Program Studi Teknik Industri perlu upaya lebih besar dalam menganalisis kebutuhan lingkungan khususnya industry baik barang maupun jasa yang menjadi landasan dalam menyusun kurikulum berisikan mata kuliah menarik yang dapat menghasilkan lulusan yang berdaya saing tinggi, perkuliahan yang menarik sehingga tidak dirasakan beban oleh mahasiswa.

\subsection{Hasil Profil Responden Angkatan 2016 dan Angkatan 2017}

Hasil penelitian menunjukkan bahwa angkatan 2016 dan 2017 banyak yang mendaftar ke universitas lain selain Universitas XYZ yaitu sebesar 58,9\% dan 61\%. Adapun universitas yang paling diminati adalah ITB dan Universitas Parahyangan 73\% angkatan 2016 dan sebesar $62 \%$ angkatan 2017, selebihnya yang diminati adalah Universitas Telkom dan Binus sebesar $21 \%$ oleh angkatan 2017.

Hasil pengumpulan data menunjukkan 29 mahasiswa menyatakan mereka menetapkan pilihan Teknik Industri Universitas XYZ dengan mencari referensi terlebih dahulu. Program Studi yang terlintas di pikiran mereka tersebut didukung oleh data dimana 49.3\% angkatan 2016 memiliki saudara yang sedang/pernah berkuliah di Universitas XYZ (di program studi Teknik Industri dan Akuntansi sebesar 23.3\%, selanjutnya 20.9\% di Manajemen) dan untuk angkatan 2017 memiliki 55,2 $\%$ saudara yang sedang/pernah berkuliah di Universitas XYZ di program studi Teknik Industri sebesar 22.2\%, Akuntansi 20\%, Manajemen $15.6 \%$

Kondisi word of mouth tersebut dapat memperkuat maupun melemahkan citra Universitas XYZ. Hasil penelitian menunjukkan bahwa di pikiran mahasiswa ketika mendengar nama Universitas XYZ, baik angkatan 2016 maupun 2017 terlintas program studi Kedokteran dengan persentase 41.7 $\%$ dan $44.3 \%$, diikuti urutan selanjutnya yaitu terlintas program studi Teknik Industri dengan persentase $20.2 \%$ dan $27.1 \%$ serta program studi manajemen dengan persentase $17.9 \%$ dan $11.4 \%$.

Berdasarkan asal SMA terbanyak mahasiswa berasal dari Bandung sebesar 30 orang (42\%) untuk angkatan 2016 dan sebesar 28 orang (53\%) untuk angkatan 2017. Mahasiswa yang berasal dari luar Bandung berkisar $47 \%-58 \%$. 
Berdasarkan gelombang pendaftaran diketahui bahwa 72 orang angkatan 2016 paling banyak berasal dari jalur pendaftaran PMDK dan USM Juli dengan persentase yang sama yaitu 24.7\%. Berikutnya sebesar $16.4 \%$ mahasiswa berasal dari jalur pendaftaran USM Mei, $15.1 \%$ dari jalur USM Agustus. Dan yang paling sedikit berasal dari USM Desember dan Februari dengan persentase yang sama sebesar 9.6\%. Sedangkan dari 59 orang angkatan 2017 memiliki profil yang sedikit berbeda yaitu paling banyak berasal dari jalur pendaftaran PMDK $42.4 \%$. Selanjutnya $27.1 \%$ berasal dari USM Juli, $15.3 \%$ USM Agustus, $8.5 \%$ USM Mei. Dan yang paling sedikit sama berasal dari USM Desember dan Februari yaitu 3.4\%.

Diketahui bahwa dari 79 responden diperoleh 95 data sumber info Teknik Industri Universitas XYZ di angkatan 2016. Sumber info yang paling banyak diketahui adalah pilihan lainnya dengan persentase $38.9 \%$. Terbanyak kedua adalah info melalui kunjungan UKM ke SMA dengan persentase $24.2 \%$. Selanjutnya adalah dari promosi pihak sekolah sebesar $12.6 \%$, edufair sebesar $9.5 \%$, spanduk sebesar 7.4\%, kunjungan SMA ke UKM sebesar 3.2\%, dan terakhir melalui iklan koran dan radio dengan persentase yang sama yaitu sebesar $2.1 \%$. Sedangkan dari 59 responden diperoleh 96 data sumber info Teknik Industri Universitas XYZ di angkatan 2017. Sumber info yang paling banyak diketahui adalah pilihan lainnya dengan persentase $30.2 \%$. Terbanyak kedua adalah info melalui kunjungan UKM ke SMA dengan persentase $22.9 \%$. Selanjutnya adalah dari edufair sebesar $17.7 \%$, kunjungan SMA ke UKM sebesar 10.4\%, promosi pihak sekolah dan spanduk sebesar 8.3\%, dan terakhir melalui iklan koran dan radio dengan persentase yang sama yaitu sebesar $1 \%$. Universitas XYZ perlu lebih memperhatikan upaya promosi yang intensif khususnya tentang PMDK ke sekolahsekolah melalui edufair.

\section{Kesimpulan dan Saran}

\subsection{Kesimpulan}

1. Hasil pengolahan untuk angkatan 2016 diperoleh koefisien determinasi $28,1 \%$, dengan Variabel yang berpengaruh terhadap pemilihan program studi Teknik Industri Universitas XYZ serta meningkatkan keyakinan pemilihan program studi Teknik Industri adalah Peringkat Universitas dibandingkan dengan universitas negri dan swasta lainnya (X11), Kemudahan mendapatkan tempat kost (X32), Menariknya talk show promosi Teknik Industri di radio (X54) dan Banyaknya publikasi buku yang ditulis oleh dosen program studi Teknik Industri (X59).

Sedangkan untuk angkatan 2017 diperoleh koefisien determinasi 44,4 \%, dengan Variabel yang berpengaruh terhadap pemilihan program studi Teknik Industri Universitas XYZ serta meningkatkan keyakinan pemilihan program studi Teknik Industri adalah Peringkat Universitas dibandingkan dengan universitas negri dan swasta lainnya (X11), Luas ruang kuliah (X21), Universitas memiliki banyak unit kegiatan mahasiswa yang sesuai minat mahasiswa (X26), dan Menariknya mata kuliah yang diajarkan di program studi Teknik Industri (X45).

Persamaan variabel yang berpengaruh dari kedua angkatan tersebut adalah variabel peringkat universitas.

Variabel yang berpengaruh baik dari kedua angkatan tersebut merupakan aktor-faktor yang dianggap penting mengenai suatu perguruan tinggi oleh siswa SMA pada penelitian Yulianti \& Gozaly (2008), beberapa diantaranya adalah: status akreditasi dari program studi kenyamanan ruang kuliah. Yang membedakan adanya publikasi buku yang ditulis oleh dosen program studi Teknik Industri.

2. Mempertimbangkan persamaan antara angkatan 2016 dan 2017 tentang variabel yang berpengaruh terhadap pemilihan program studi dan universitas, yaitu variabel peringkat universitas yagn dibandingkan dengan universitas lainnya, maka sebaiknya usulan Program Studi Teknik Industri perlu upaya lebih besar mencapai peringkat minimal sama bahkan melebihi peringkat universitas lainnya, karena itu Teknik Industri Universitas X perlu dalam menganalisis kebutuhan lingkungan khususnya industry baik barang maupun jasa yang menjadi landasan dalam menyusun kurikulum berisikan mata kuliah menarik yang dapat menghasilkan lulusan yang berdaya saing tinggi, perkuliahan yang menarik sehingga tidak dirasakan beban oleh mahasiswa. 
Dengan pilihan pendidikan yang terus meningkat, calon siswa mencari institusi yang akan memberi mereka pengetahuan pendidikan yang berbeda, mencari program pendidikan yang akan mempersiapkan mereka untuk profesi yang sukses dan yang akan memberi mereka pekerjaan yang menguntungkan (Kargic, 2013). Universitas XYZ perlu mendukung kegiatan publikasi dalam hal pendanaan dan diikuti oleh banyaknya dosen berpartisipasi menulis dan mempublikasikan buku. Universitas XYZ perlu lebih memperhatikan upaya promosi yang intensif khususnya tentang PMDK ke sekolah-sekolah melalui edufair dan kunjungan Universitas XYZ ke sekolah langsung pada saat jam pelaksanaan pembelajaran dilakukan.

\subsection{Saran}

Untuk memperoleh gambaran faktor pemilihan program studi sebaiknya dapat dilakukan penelitian dengan pengambilan sampel mahasiswa angkatan 2018 dst. dengan menggunakan variabel bebas kinerja faktor-faktor pemilihan universitas dan program studi dari Alonderiene (2013) dan variabel terikat tingkat keyakinan pemilihan Program Studi Teknik Industri Universitas XYZ.

\section{Ucapan Terima Kasih}

Ucapan terima kasih kami sampaikan kepada Linda dan Gratia Melina yang telah membantu proses pengumpulan dan pengolahan data

\section{Daftar Pustaka}

Alonderiene, Raimonda, Asta Klimaviciene (2013), Insights Into Lithuanian Students's Choice of University and Study Program in Management and Economics, Management, 18, 1-22

Hair, Joseph F. (2014), Multivariate Data Analysis, Pearson Education Limited.

Kargic Lejla, Mersid Poturak (2013), Factors that Influence State or Private University Selection, European Journal of Contemporary Education, 9(3), 149-159.

Kotler, Keller (2016), Marketing Management, Global Edition 1, 15 e, Pearson.

Kusumawati, Andriani (2013), A Qualitative Study of the Factors Influencing Student Choice: The Case of Public University in Indonesia, Journal of Basic and Applied Scientific Research, 3(1), 314327.

Manoku, Elfrida (2014), Factors that Influence University Choice of Albanian Students, European Scientific Journal, June 2015, Vol. 11, No.16, 253-270

Muniady, Rajennd, et. al. (2014), Factors Influencing Consumer Behavior: A Study among University Students in Malaysia, Asian Social Science, 10(9), 18-25.

Muskinja, Jovan, et. al. (2013), The Need for Appropriate Marketing Mix Implementation at Serbian Universities. Journal of XIX Skup TRENDOVI RAZVOJA, T1.1-5, 18-21

Sekaran, Uma (2016), Research Methods for Business, A Skill Building Approach, Seven Edition, John Wiley \& Sons, Inc.

Yulianti \& Gozaly J. (2008), Usulan Bauran Pemasaran dalam Upaya Meningkatkan Jumlah Mahasiswa Baru Universitas XYZ" (studi kasus Siswa SMA di Kota Bandung).

Yulianti \& Sutjiati R. (2008), Usulan Bauran Pemasaran dalam Upaya Meningkatkan Jumlah Mahasiswa Baru Universitas XYZ" (studi kasus Siswa SMA di Wilayah Jawa kecuali Kota Bandung). 